\title{
$\mathrm{CFD}$ 검증용 데이터베이스 구축을 위한
} 손상 선박의 횡동요 감쇠 운동에 대한 실험적 연구

\author{
이성균 $\cdot$ 유지명 $\cdot$ 이현호 ${ }^{2 \dagger} \cdot$ 이신형,3. 이기표,3 \\ 서울대학교 조선해양공학과 \\ 현대중공업(주) 선박해양연구소 ${ }^{2}$ \\ 서울대학교 조선해양공학과 해양시스템공학연구소 ${ }^{3}$
}

\section{Experimental Study on Free Roll Decay Motions of a Damaged Ship for CFD Validation Database}

\author{
Sungkyun Lee $\cdot$ Ji-Myoung You' $\cdot$ Hyun-Ho Lee ${ }^{2 \dagger} \cdot$ Shin Hyung Rhee ${ }^{1,3} \cdot$ Key-Pyo Rhee ${ }^{1,3}$ \\ Department of Naval Architecture and Ocean Engineering, Seoul National University ${ }^{1}$ \\ Hyundai Maritime Research Institute, Hyundai Heavy Industries Co., Ltd. ${ }^{2}$ \\ Department of Naval Architecture and Ocean Engineering, Research Institute of Marine Systems Engineering, Seoul National University ${ }^{3}$
}

\begin{abstract}
Among many factors to be considered for higher safety level requirements, the hull stability in intact and damaged conditions in seaways is of utmost importance. Since the assessment of a damaged ship is complicated due to the highly non-linear behavior, it is widely acknowledged that computational fluid dynamics (CFD) methods are one of the most feasible approaches. Although many research activities are being reported on the damaged ship stability recently, most of them are not designed for validation of CFD studies. In this study, well-designed model tests were performed to build a CFD validation database, which is essential in developing better CFD methods for the damage stability assessment. The geometry of the damaged compartment and test conditions were determined based on preliminary CFD simulations. Free roll decay tests in calm water with both intact and damaged ships were performed and the roll motion characteristics were compared. The damaged ship showed a larger roll damping coefficient and more rapid decrease of roll amplitude than the intact ship. The primary reason of these efforts can be explained by the movement of the flooded water.
\end{abstract}

Keywords : Free roll decay test (자유 횡동요 감쇠 시험), Damaged ship stability (손상 선박 안정성), CFD validation (CFD 검증),Roll damping coefficient (횡동요 감쇠 계수)

\section{1. 서 론}

선박 설계에 있어서 가장 기본적이고도 중요한 문제 중의 하나 는 운항 안정성이다. 특히 손상 시의 안정성은 최근 더욱 중요시 되고 있는데, 그 이유는 여객선 수의 증가에 따른 국제적인 규약 이 더 심화되었기 때문이다. 손상 시의 안정성 문제는 비 손상 시 의 안정성 문제에 비해서 비선형 특성이 매우 강하고 복잡하다. 따라서 CFD를 이용한 해석이 손상 시 안정성을 분석할 수 있는 좋은 방법으로 각광을 받고 있다.

손상 시 안정성에 관한 연구는 많은 연구자들에 의해서 수행되 어 왔다. Papanikolaou, et al. (2000)은 RO-RO 여객선의 손상 시 파랑 중 전복에 관한 연구를 수행한 바 있고, Palazzi, et al. (2004)은 소형 구축함이 손상된 경우에 대한 모형시험과 수치계
산을 수행하였다. 또한, Ruponen (2007)은 손상된 여객선의 내 부로 유입되는 유동에 대한 수치계산을 수행하여 점진적인 침수 에 대한 연구를 수행하였다.

선박의 손상 시 안정성에 관한 많은 실험적 연구가 수행되었음 에도 불구하고, CFD 검증을 위한 실험은 거의 없는 실정이다. Helsinki 대학 (Ruponen, 2007)에서 매우 단순한 형상인 바지선 에 대한 침수 모형시험을 수행한 바 있으나 내부의 침수 구획이 상당히 복잡하게 설계되어 있기 때문에 결과의 불확실성도 증가 하게 되어 CFD 계산 결과의 검증용 자료로 활용하기에는 어려움 이 있다. CFD 계산 결과의 검증용 데이터베이스를 구축하기 위 한 실험을 설계하기 위해서는 불명확한 요인들을 최대한 제거해 야만 한다. 우선, 간단한 손상 구획과 기본적인 경우에 대한 CFD 계산이 검증되고 점진적으로 CFD 방법을 향상시켜 추후 복잡한 손상 시의 안정성 문제를 해결해 나가야 할 것이다. 그러므로 본 
연구의 목표는 다음과 같다. (1) 사전 CFD 시뮬레이션 결과를 반 영한 모형시험 계획, (2) 손상 시와 비 손상 시 선박의 정수 중 횡동요 자유감쇠 실험 수행, (3) 계측된 실험 데이터를 통한 CFD 검증용 데이터베이스 구축.

본 연구의 대상 선형은 영국 University of Strathclyde의 Ship Stability Research Center (SSRC)에서 제공한 여객선을 이용하 였다. 모형선의 자세는 관성 계측 장치 (Inertial Measurement Unit, IMU)와 가속도계들의 조합을 이용하여 계측하였다. 침수 구획 내부에 유입된 유동의 거동을 측정하기 위하여 침수 구획 내부에는 파고계들을 설치하였고 침수 구획의 선수와 선미 쪽에 는 $\mathrm{CCD}$ 카메라를 설치하였다.

\section{2. 사전 $\mathrm{CFD}$ 계산}

CFD 검증용 모형시험을 계획하기 위해서는 우선 현재 CFD의 수준을 파악해야 한다. 따라서 모형시험에 앞서 몇 개의 단순화 된 사례들에 대하여 사전 CFD 계산을 수행하였다. 계산에 사용 된 프로그램은 CFDSHIP-IOWA이다. 모형시험을 수행하기 전에 미리 CFD 계산을 수행해 봄으로써 모형시험 시 손상 구획의 형 상 및 계측해야 할 항목과 시험조건 등을 결정하였다. CFD 프로 그램에 따라 결과의 정량적 차이가 존재함을 확인하였고 경사시 험이나 자유 횡동요 감쇠 시험과 같은 선행 모형시험의 결과가 검증용으로 필요한 것을 확인하였다. 또한 손상 시 선박의 손상 구획은 최대한 단순화된 형상으로 제작되었다.

\section{1 바지선의 파랑 중 횡동요}

첫 번째 사례로, 바지선의 횡동요 운동을 계산하였다. 대상 선 형은 Chen, et al. (2002)이 대파고 중 전복 문제의 계산에 사용 했던 폰툰 형 바지선을 선정하였는데 형상이 간단하고 계산 결과 를 기존의 계산 결과와 비교할 수 있다는 장점이 있다. 대상 선박 의 주요 제원은 Table 1에 나타내었고, 계산에 사용된 파도의 조 건은 Table 2에 나타내었다.

Table 1 Principal dimensions of the barge

\begin{tabular}{c|c}
\hline Parameters & Value (Unit) \\
\hline Length & $36.58(\mathrm{~m})$ \\
\hline Beam & $7.62(\mathrm{~m})$ \\
\hline Height & $3.048(\mathrm{~m})$ \\
\hline Draft & $1.829(\mathrm{~m})$ \\
\hline Mass & $4.814 \times 10^{5}(\mathrm{~kg})$ \\
\hline VCG (above the keel) & $3.44(\mathrm{~m})$ \\
\hline Roll radius of gyration & $3.478(\mathrm{~m})$ \\
\hline GM & $0.12(\mathrm{~m})$ \\
\hline Water depth & $7.315(\mathrm{~m})$ \\
\hline
\end{tabular}

Chen, et al. (2002)은 Reynolds-averaged Navier-Stokes (RANS) 방법과 CHIMERA 중첩격자시스템을 이용하여 수심
$7.315 \mathrm{~m}$ 의 유한 수심에서 우현 (90 도)으로부터 파도가 들어오 는 경우 2 차원 단면 형상에 대한 계산을 수행하였다. 본 논문에 서는 CFDSHIP-IOWA 프로그램과 SUGGAR 중첩 격자 시스템을 이용하여 3 차원 형상에 대한 계산을 실시하였다. 또한 수심의 변화에 따른 선박의 횡동요 거동의 차이를 살펴보기 위하여 수심 $7.315 \mathrm{~m}$ 의 유한 수심 조건과 무한 수심 조건에 대한 계산을 수 행하였다.

대상 바지선은 무게중심의 수직방향 위치가 $3.44 \mathrm{~m}$ 로 높기 때 문에 파랑 강제력에 의해 큰 횡동요가 발생하며, 약 $1.12 \mathrm{~m}$ 의 낮 은 건현 때문에 갑판 침수가 쉽게 발생할 것을 예상할 수 있다.

Table 2 Simulation conditions

\begin{tabular}{c|c}
\hline Parameters & Value (Unit) \\
\hline Wavelength & $21.95(\mathrm{~m})$ \\
\hline Wave height & $1.463(\mathrm{~m})$ \\
\hline Wave direction & $90(\mathrm{deg})$ \\
\hline Wave period (infinite depth) & $3.75(\mathrm{sec})$ \\
\hline Wave period (finite depth) & $3.806(\mathrm{sec})$ \\
\hline
\end{tabular}
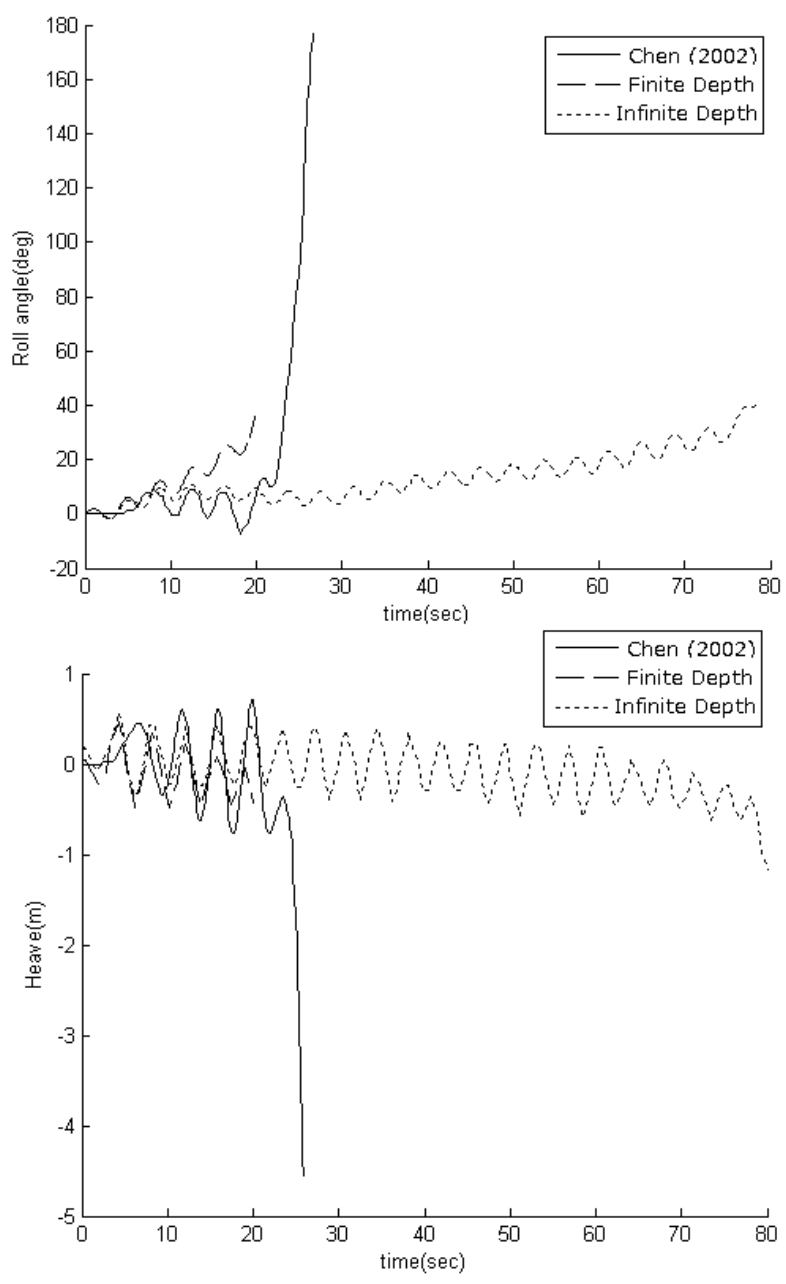

Fig. 1 Time histories of roll and heave motions 
계산된 상하동요와 횡동요 응답의 시계열을 Chen, et al. (2002)의 결과와 비교하여 Fig. 1에 나타내었다. 유한 수심에서 의 계산 결과는 Chen, et al. (2002)의 결과와 상당한 차이를 보 이고 있으며 대체로 두 경우 모두 25 초 이내에 전복되는 결과를 보이고 있다. 두 가지 프로그램 모두 동일한 난류 모델의 RANS 기법을 사용하고 있으나 서로 다른 중첩 격자 시스템을 사용하고 있는 것이 결과 차이의 주요 원인으로 사료된다. 시간에 따라 격 자가 이동하는 경우 격자 상태를 양호하게 유지하면서 계산 시간 을 줄이는 것이 관건이며, 이를 위해 중첩 격자 시스템에 따라 서 로 다른 방법으로 격자들을 처리하고 있기 때문이다.

유한 수심에 대한 계산에서는 무한 수심에서의 계산 보다 전복 이 훨씬 빨리 일어나는 것을 확인할 수 있다. 두 경우 모두 입사 파의 파고와 파장은 같으나 수심의 영향으로 파의 주기는 차이가 있다 (Table 2 참조). 또한 유한 수심의 경우 파랑 입자의 운동이 무한 수심의 경우보다 타원형으로 일어났을 것이며 이것이 선저 압력의 변화를 유발할 수 있었을 것으로 사료된다. 선저 압력의 차이로 시뮬레이션 초기에 유한 수심에서의 횡동요 각이 조금 더 크게 발생하고 시간에 따라 이러한 차이가 크게 나타난 것으로 추정된다.

\section{2 침수 구획 내의 침수 유동}

선박이 손상되고 물이 손상 부위를 통하여 선박 내부로 들어오 게 되면 손상된 선박의 거동은 침수 유동에 의해 상당한 영향을 받는다. 본 연구에서는, 모형선의 침수 구획의 형상을 결정하기 위하여 사전 CFD 계산을 수행하였다. 시뮬레이션은 불확실성 인 자를 가능한 한 많이 줄일 수 있는 간단한 침수 구획 형상을 가지 고 수행되었다. Cho, et al. (2006)은 CFD 코드인 FLOW-3D를 이용하여 실제 모델과 단순화된 모델의 두 가지 침수 구획 모델 을 선정하여 침수 구획에 물이 유입하는 문제에 대한 계산을 수 행하였다.

Table 3 Main dimensions of the damaged compartment

\begin{tabular}{c|c}
\hline Parameters & Value (Unit: m) \\
\hline Length & 0.55 \\
\hline Breadth & 0.515 \\
\hline Height & 0.186 \\
\hline Draft & 0.132 \\
\hline Damaged length & 0.17 \\
\hline
\end{tabular}

본 연구에서는 Cho, et al. (2006)이 사용한 두 가지 침수 구 획 모델 중 Table 3에 나온 것과 같은 단순화된 모델에 대하여 CFDSHIP-IOWA와 FLUENT, 두 가지 다른 CFD 코드를 이용하여 수치계산을 수행하였으며 그 결과들을 Cho, et al. (2006)의 결
과들과 비교하였다. CFD 계산은 동일한 계산 조건과 계산 영역 에서 수행되었다.

Fig. 2는 동일한 순간에서의 침수 시뮬레이션 계산 결과를 비 교하여 나타내고 있다. 사용된 CFD 코드에 따라 침수 속도와 자 유표면 형상 등 침수 과정에 차이가 존재함을 확인할 수 있다. 시 뮬레이션 결과의 차이는 사용된 격자의 크기 및 자유표면의 생성 방식 등에 의한 것으로 사료된다. CFDSHIP-IOWA는 자유표면을 계산할 때 level-set 방법을 활용하며 FLOW-3D와 FLUENT의 경 우에는 VOF (Volume of fluid) 방법을 사용한다. VOF 방법은 상 대적으로 계산 시간은 많이 걸리지만 좀 더 현상을 사실적으로 예측할 수 있다는 장점이 있으며 level-set 방법은 VOF 방법 보 다 정확도는 떨어지지만 계산 시간이 단축된다는 장점이 있다.

이러한 침수 문제는 초기의 침수 구획 내부 자유표면이 급격히 변화하며 내부 공기의 압축 효과까지 고려해야 한다는 어려움이 있고 아래의 계산들 중 어떠한 계산이 실제 현상과 맞는지 명확 하게 알 수 없다. Cho, et al.(2006)은 FLOW-3D를 이용한 해석 결과와 모형시험 결과를 비교하였지만 CFD 기법의 가능성과 정 도를 확인한 정도였다. 그러므로 우선은 최대한 간단한 침수 구 획에 대한 CFD 검증용 실험 데이터베이스가 필요하다는 결론을 얻었고 간단한 침수 구획을 이용하여 모형시험이 수행되었다.

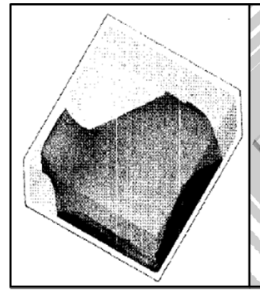

Cho etal(2006)

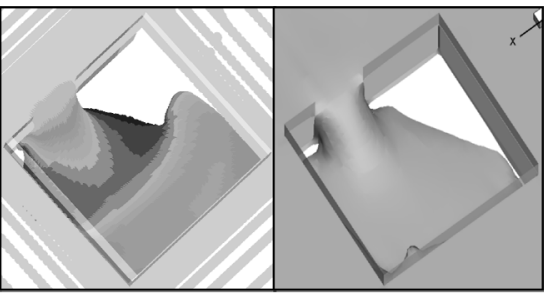

CFDSHIP-IOWA
FLUENT
Fig. 2 Snapshots of the flooded water surface at $t=3.0$ sec

\section{3. 모형시험 대상과 시험조건}

\section{1 모형선}

앞서 언급한 바 있는 본 연구의 대상 선박은 ITTC에서 손상 선 박의 안정성 문제에 대한 비교 시험에 사용되었던 것이며, 한국 해양연구원에서도 손상 선박의 안정성 연구를 위하여 채택된 바 있다.

모형시험은 길이 $110 \mathrm{~m}$, 폭 $8 \mathrm{~m}$, 깊이 $3.5 \mathrm{~m}$ 인 서울대학교 예인수조에서 수행하였다. 모형선의 길이는 예인수조의 크기와 ITTC 권고 기준을 고려하여 $3 \mathrm{~m}$ 로 결정하였고 실선과의 축척 비는 82.57이다. 경사시험을 통해 모형선의 무게중심과 관성모 멘트를 조정하였으며 대상 선박과 모형선의 주요 치수는 Table 4에 나타내었다. Fig. 3은 선박의 손상 구획과 모형선을 나타내 고 있다. 
Table 4 Principal dimensions of the ship and model

\begin{tabular}{|c|c|c|c|}
\hline \multicolumn{2}{|c|}{ Item } & $\begin{array}{l}\text { Prototype } \\
\text { value }\end{array}$ & $\begin{array}{l}\text { Model } \\
\text { value }\end{array}$ \\
\hline \multicolumn{2}{|c|}{ Lpp (m) } & 247.7 & 3.0 \\
\hline \multicolumn{2}{|c|}{ Beam (m) } & 35.5 & 0.43 \\
\hline \multicolumn{2}{|c|}{ Draft (m) } & 8.3 & 0.1 \\
\hline \multicolumn{2}{|c|}{ Disp. (ton) } & 56541.5 & 0.1 \\
\hline \multicolumn{2}{|c|}{$\begin{array}{c}\text { LCB }(\mathrm{m}) \\
\text { (+: forward of the midship) }\end{array}$} & -3.096 & -0.037 \\
\hline \multicolumn{2}{|c|}{$\begin{array}{c}\text { LCG }(\mathrm{m}) \\
\text { (+: forward of the midship) }\end{array}$} & -6.329 & -0.077 \\
\hline \multicolumn{2}{|c|}{$\mathrm{KB}(\mathrm{m})$} & 4.085 & 0.049 \\
\hline \multicolumn{2}{|c|}{$\mathrm{KM}(\mathrm{m})$} & 18.781 & 0.227 \\
\hline \multirow{2}{*}{$K G(m)$} & desired & 16.393 & 0.199 \\
\hline & measured & . & 0.197 \\
\hline \multirow{2}{*}{$\mathrm{GM}(\mathrm{m})$} & desired & 2.388 & 0.029 \\
\hline & measured & . & 0.029 \\
\hline \multirow{2}{*}{$k x x(m)$} & desired & 14.814 & 0.179 \\
\hline & measured & . & 0.176 \\
\hline \multirow{2}{*}{ kyy (m) } & desired & 61.925 & 0.750 \\
\hline & measured & . & 0.751 \\
\hline
\end{tabular}

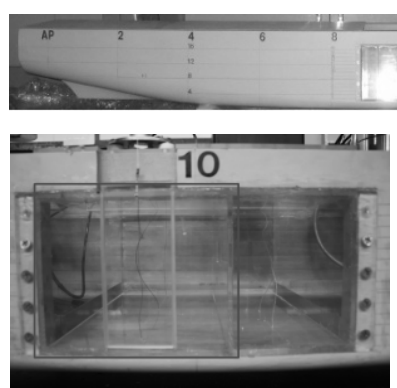

〈Side view>

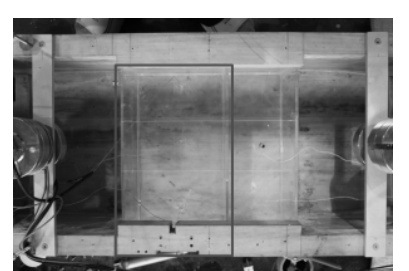

$\langle$ Plan view>
Fig. 3 Model ship with damaged compartment

\section{2 침수 구획}

침수 구획은 Fig. 3에서와 같이 선체 중앙부에 위치하며 투명 한 아크릴을 이용하여 제작하였는데 형상은 Fig. 4와 같다. 침수 구획은 좌우 비대칭이며 침수 구획의 천장에는 두 개의 구멍을 뜷어 내부와 외부의 공기가 드나들 수 있도록 (ventilation type) 하였다. 침수 구획 내부로 유입된 물의 수위를 측정하기 위하여 침수 구획 내부에 3 개의 용량식 파고계를 설치하였고 유입수의 거동을 관찰하기 위해 침수 구획의 전후에 비디오카메라를 설치 하였다.

침수 유동에 영향을 줄 수 있는 중요한 요인 중의 하나는 침수 된 곳의 수문이 열리는 시간이다. 본 연구에서는 수문이 0.09 초 내에 열리도록 하였으며 효과적으로 재빠른 가속도를 낼 수 있는
공기압 실린더 (air cylinder)를 이용하여 수문을 들어 올리는 메 커니즘을 구현하였다.

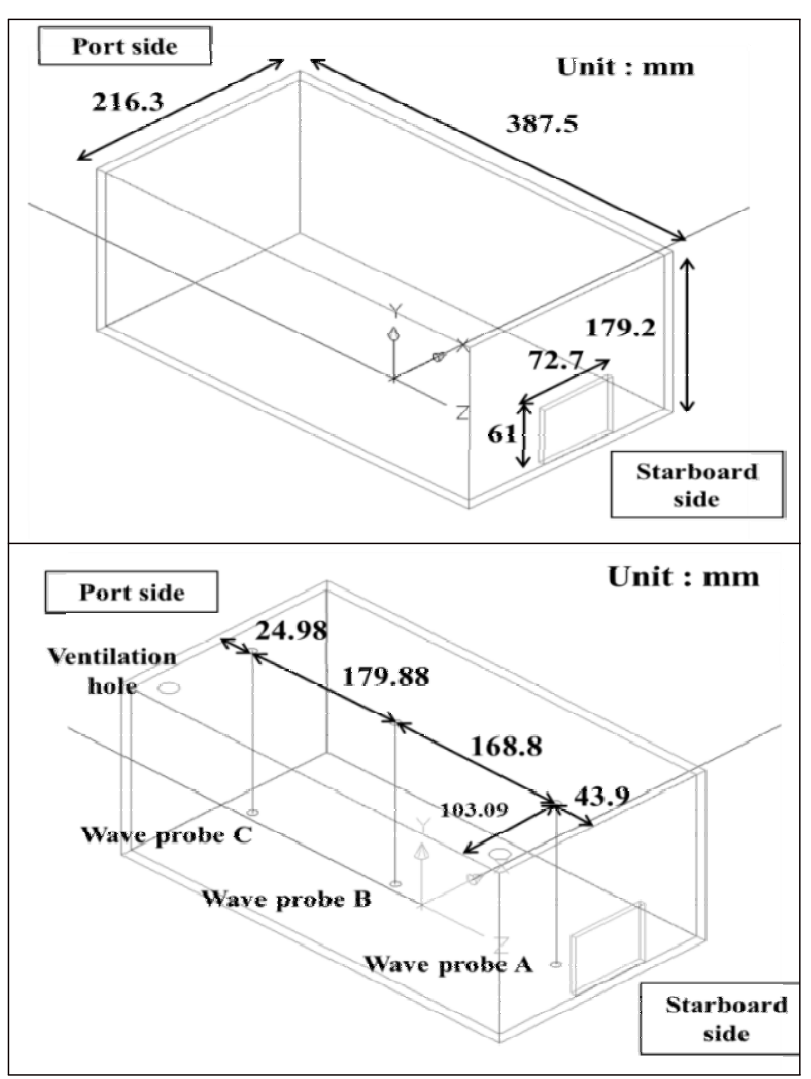

Fig. 4 Geometry of the damaged compartment

\section{4. 모형시험 결과}

정수 중 자유 횡동요 감쇠 시험을 실시하였으며, 이 시험을 통 하여 모형선의 횡동요 감쇠 계수를 추정하였다.

\section{1 횡동요 감쇠 계수 추정 방법}

선박의 1 자유도 선형 횡동요 운동 방정식은 식 (1)과 같이 표 현할 수 있다.

$\left(I_{44}+A_{44}\right) \ddot{\phi}+B_{44} \dot{\phi}+\triangle \overline{G M} \phi=0$

식 (1)에서 $I_{44}$ 는 횡동요 질량 관성모멘트를, $A_{44}$ 는 횡동요 부가질량 관성모멘트를, $\phi$ 는 횡동요 각을, $B_{44}$ 는 선형 횡동요 감쇠 계수를, $\triangle$ 는 선박의 배수량을, $\overline{G M}$ 은 선박의 무게중심 에서 메타센터까지의 거리를 각각 의미한다.

본 논문에서 모형선의 횡동요 감쇠 계수는 두 가지의 다른 해 석 방법을 통해 산출되었다. 하나는 횡동요 운동 진폭이 대수적 으로 감소한다는 (logarithmic decrement) 가정을 이용하는 방법 
이고, 다른 하나는 횡동요의 반 주기 동안 소실된 에너지를 고려 하는 방법 (energy method)이다.

먼저, 대수 감소 방법은 시간에 따라 횡동요 운동 진폭이 줄어 드는 비율을 이용하여 얻을 수 있다.

식 (1)을 아래와 같이 다르게 표현하자.

$\ddot{\phi}+2 \zeta \omega_{n} \dot{\phi}+\omega_{n}^{2} \phi=0$

식 (2)에서 좌변의 계수들은 식 (1)로부터 각각 아래와 같이 정의된다.

$\frac{B_{44}}{\left(I_{44}+A_{44}\right)}=2 \zeta \omega_{n}, \quad \frac{\Delta \overline{G M}}{\left(I_{44}+A_{44}\right)}=\omega_{n}^{2}$

횡동요 자유감쇠 운동은 과소 감쇠 (under-damped) 조화운동 이므로 식 (2)의 일반해는 다음과 같다.

$$
\begin{gathered}
\phi=A e^{-\zeta \omega_{n} t} \sin \left(\omega_{d} t+\epsilon\right), \\
\text { where } \omega_{d}=\omega_{n} \sqrt{1-\zeta^{2}}
\end{gathered}
$$

식 (3)과 (4)를 이용하면 횡동요 감쇠 계수는 아래와 같이 나 타낼 수 있다.

$$
B_{44}=2\left(I_{44}+A_{44}\right) \zeta \frac{\omega_{d}}{\sqrt{1-\zeta^{2}}}
$$

대수 감소에서 $\zeta$ 는 식 (4)의 일반해와 횡동요 운동진폭의 비 를 이용하여 식 (6)과 같이 구할 수 있다.

$$
\zeta=1 / \sqrt{1+\left(2 \pi / \ln \left(\frac{x\left(t_{n}\right)}{x\left(t_{n+1}\right)}\right)\right)^{2}}
$$

한편, 에너지 방법을 적용할 경우 반 주기 동안의 횡동요 에너 지를 구하기 위해 횡동요 방정식의 양변에 횡동요 각속도를 곱하 고 반 주기 동안의 적분을 통해 횡동요 감쇠계수를 얻게 된다.

식 (2)에서 좌변의 계수들을 식 (7)과 같이 정의하면,

$$
\frac{B_{44}}{\left(I_{44}+A_{44}\right)}=2 \kappa, \quad \frac{\Delta \overline{G M}}{\left(I_{44}+A_{44}\right)}=\omega_{n}^{2}
$$

횡동요 운동방정식은 아래와 같이 표현된다.

$$
\ddot{\phi}+2 \kappa \dot{\phi}+\omega_{n}^{2} \phi=0
$$

반 주기 동안 횡동요 진폭의 감소가 작다고 가정하고, 횡동요
반 주기 동안의 거동을 평균진폭 $\bar{\phi}$ 를 갖는 조화운동으로 근사하 면, $\mathrm{n}$ 번째 반 주기의 횡동요 운동은 다음과 같이 기술할 수 있다.

$\phi(t) \cong \overline{\phi_{n}} \cos \omega_{n} t$

식 (9)와 같은 가정을 도입하여 횡동요 진폭과 주기만을 이용 하여 횡동요 감쇠 계수를 구할 수 있다. 우선, 식 (8)의 운동방정 식 양변에 횡동요 각속도 $(\dot{\phi})$ 를 곱하고 반 주기 동안 시간에 대 해 적분을 수행한다.

$\int_{0}^{T / 2} \ddot{\phi} \dot{\phi} d t+\int_{0}^{T / 2} 2 \kappa \dot{\phi} \dot{\phi} d t+\int_{0}^{T / 2} \omega_{n}^{2} \phi \dot{\phi} d t=0$

식 (10)에 식 (9)를 대입하면 평균 횡동요 진폭과 횡동요 차이 를 나타내는 변수로 식을 표현할 수 있다. 식 (10)의 첫째 항은 횡동요 진폭이 최대일 때 속도가 0인 것을 이용하면 0이 되고 셋 째 항은 반 주기 동안 횡동요 진폭의 차이를 이용하여 표현할 수 있다.

$$
\begin{gathered}
0+2 \kappa \omega_{n}^{2} \overline{\phi_{n}^{2}} \frac{T}{4}-\omega_{n}^{2} \overline{\phi_{n}} \Delta \phi_{n}=0 \\
\text { where } \Delta \phi_{n}=\phi_{n+1}-\phi_{n}
\end{gathered}
$$

식 (8)의 $\kappa$ 는 평균 횡동요 진폭과 횡동요 주기를 이용하여 아 래와 같이 나타낼 수 있다.

$\kappa=\frac{2 \Delta \phi_{n}}{T \overline{\phi_{n}}}$

식 (12)를 식 (7)에 대입하여 횡동요 감쇠 계수를 산출할 수 있다.

\section{2 비 손상 시의 횡동요 자유감쇠 실험}

손상 선박의 모형시험에 앞서 비 손상 선박에 대한 시험을 먼 저 실시하였다. 모형선은 29.3 도의 초기 횡경사각으로 기울여진 상태에서 자유 횡동요를 시작하였다. 초기 경사각은 극심한 상황 을 재현하기 위해 대경사각인 29.3 도로 정해졌으며, 반복성 확 인을 위해 실험은 모든 경우에 대하여 세 번씩 진행되었다. 모형 선의 운동을 계측하기 위하여 IMU 이외에 7 개의 가속도 센서를 조합한 스트랩다운 방법도 시도되었는데, Fig. 5에는 IMU로 계측 한 횡동요 시계열과 스트랩다운 방법으로 추정한 횡동요 시계열 을 비교하여 나타내었다. Fig. 5에서 알 수 있듯이 횡동요 시계열 이 서로 잘 일치하는 것을 확인할 수 있다. 다만, 스트랩다운 방 법의 적용을 위하여 신호의 필터링이 필요한데 이 과정에서 신호 의 처음과 마지막 부분이 약간 왜곡되는 현상이 발생하고 있다. 이후에 본 논문에 수록된 결과들은 모두 IMU로 계측한 결과를 이 용한 것임을 밝힌다. 


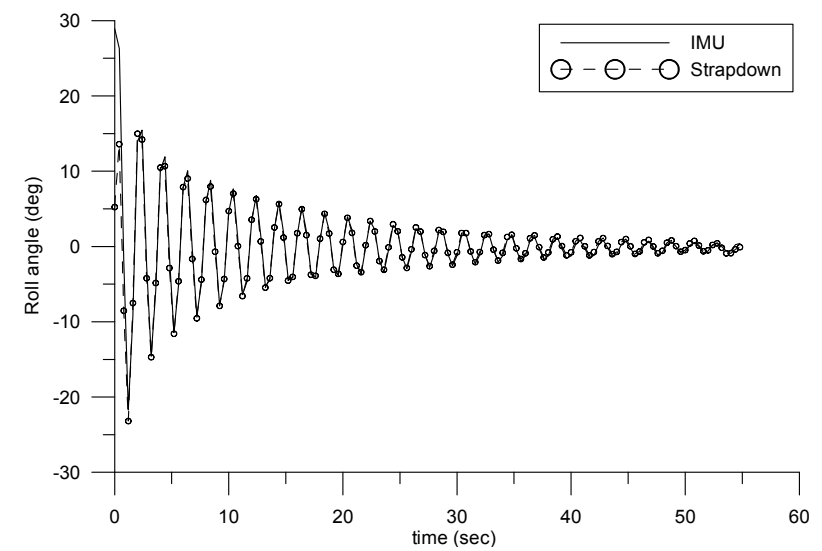

Fig. 5 Comparison of roll time histories measured by IMU and calculated by strapdown method (intact)

Table 5에는 비 손상 선박에 대한 모형시험에서 계측된 횡동 요의 평균 주기와 추정한 횡동요 감쇠 계수를 나타내었다. 횡동 요 감쇠 계수는 대수 감소 방법과 에너지 방법의 두 가지 방법으 로 산출되었고 결과들은 임계 감쇠 계수에 대한 비율로 나타내었 다. 대수 감소 방법은 시간에 따라 대수적으로 진폭이 감소한다 고 가정한 반면, 에너지 방법은 횡동요의 반 주기 동안 평균진폭 으로 감쇠 없이 운동한다는 가정했기 때문에 에너지 방법을 사용 했을 때 감쇠 계수가 조금이나마 크게 추정된 것으로 사료된다.

Table 5 Roll motion period and damping ratio (intact)

\begin{tabular}{c|c}
\hline Period of roll motion & $2.02 \mathrm{sec}$ \\
\hline$B_{44, \log } / B_{44, \text { critical }}$ & $3.07 \%$ \\
\hline$B_{44, \text { energy }} / B_{44, \text { critical }}$ & $3.11 \%$ \\
\hline
\end{tabular}

\section{3 정수 중 침수 유동}

향후 실시 예정인 파랑 중 침수 시험을 실시하기에 앞서, 정수 중에서의 침수 유동 시험을 실시하여 침수 유동의 거동을 살펴보 았다. 침수 시험은 모형선이 자유롭게 떠있는 상태에서 모형선 갑판에 설치한 공기압 실린더를 이용하여 수문을 개방하는 방식 으로 수행하였다. 침수 구획에 물이 유입된 후 유동이 안정되고 나면, 무게중심의 이동으로 인하여 모형선이 한쪽으로 횡경사각 을 가지게 된다. 이 상태에서의 횡경사각을 IMU로 계측한 값과 내부 파고계의 수위로 추정한 값을 비교하면 각각 2.03 도와 2.15 도로 유사한 값을 나타내고 있음을 확인하였다.

\section{4 손상 시 정수 중 횡동요 자유감쇠 실험}

손상 선박의 정수 중 횡동요 자유감쇠 실험은 모형선을 초기에 29.7 도로 기울여진 상태에서 시작하였다. IMU로 계측한 횡동요 응답의 시계열은 Fig. 6 에 나타내었으며, 이 시계열을 이용하여
추정한 횡동요 평균 주기와 횡동요 감쇠 계수는 Table 6에 나타 내었다.

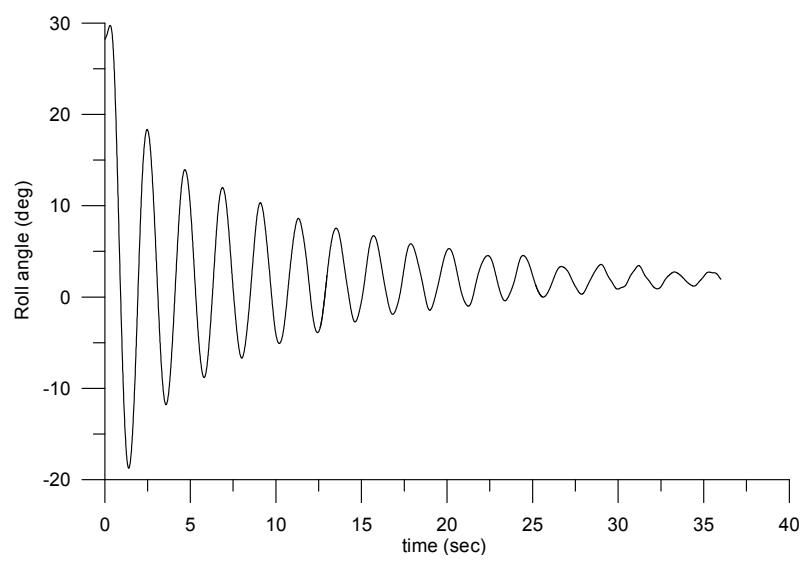

Fig. 6 Roll time history measured by IMU (damaged)

Table 6 Roll motion period and damping ratio (damaged)

\begin{tabular}{c|c}
\hline Period of roll motion & $2.22 \mathrm{sec}$ \\
\hline$B_{44, \log } / B_{44, \text { critical }}$ & $3.68 \%$ \\
\hline$B_{44, \text { energy }} / B_{44, \text { critical }}$ & $4.02 \%$ \\
\hline
\end{tabular}

Table 6에는 손상 선박의 평균 횡동요 주기와 횡동요 감쇠 계 수를 나타내었다. 비 손상 시의 경우에서도 에너지 방법은 대수 감소 방법에 비해 감쇠 계수를 크게 추정하는 경향을 보였는데 선박의 감쇠 계수가 커질수록 이러한 경향이 더욱 뚜렷해짐을 확 인하였다. Table 5 와 Table 6 을 비교하면 손상 선박의 경우 횡동 요 평균 주기는 비 손상 선박의 경우에 비해서 $10 \%$ 정도 길어졌 고, 횡동요 감쇠 계수는 $20 \%$ 이상 증가하였다. 여기서는 이러한 현상의 원인에 대해서 간단히 고찰해 보기로 한다.

우선 횡동요의 고유주기는 아래와 같이 정의된다.

$$
T=2 \pi \sqrt{\frac{I_{44}+A_{44}}{\triangle \overline{G M}}}
$$

손상 선박의 경우 침수 유동의 영향으로 인하여 모형선의 부가 질량 관성모멘트와 배수량, 그리고 $\overline{G M}$ 과 같은 변수들이 변하 게 된다. 침수 유량에 따라 선박의 횡동요 관성모멘트도 변화할 수 있겠으나 침수 유량이 약 $3 \mathrm{~kg}$ 인 것을 감안하면 이보다 $\overline{G M}$ 값이 크게 변화했을 것으로 사료된다. 따라서 손상 시 선박에 대 한 경사시험을 실시하여 손상 시 유입수가 고려된 $\overline{G M}$ 을 측정 하였으며 그 결과를 Table 7에 나타내었다. 이 결과를 보면 손상 선박의 $\overline{G M}$ 은 비 손상 선박에 비해서 약 $17 \%$ 정도 감소한 것 을 알 수 있는데 이로 인하여 손상 선박의 횡동요 주기가 길어질 수 있음을 식 (13)을 이용하여 설명할 수 있다. 
Table $7 \overline{G M}$ in intact and damaged condition

\begin{tabular}{c|c}
\hline$\overline{G M}_{I}$ (intact) & $\overline{G M}_{D}$ (damaged) \\
\hline $2.89 \mathrm{~cm}$ & $2.38 \mathrm{~cm}$ \\
\hline
\end{tabular}

다음으로 손상 선박의 횡동요 감쇠 계수가 비 손상 선박에 비 해서 증가한 원인에 대해서 살펴보기로 한다. Fig. 7은 손상 시 자유 횡동요 자유감쇠 실험에서 계측된 침수 유동의 자유표면 높 이를 시간에 따라 나타낸 것이다. 파고계 $\mathrm{A}, \mathrm{B}, \mathrm{C}$ 는 각각 선박의 우현, 중앙 그리고 좌현에 위치한다 (Fig. 4 참조).

침수 구획 내부로 유입된 유동의 자유표면의 높이는 파고계 설 치 위치에 따라 다르며 $A, B, C$ 의 순서대로 높았다. 침수 구획의 형상이 완벽한 좌우대칭이 아니기 때문에 침수 중 선박의 횡경사 가 발생했으며 이에 따라 각 파고계의 자유표면 평균 높이에 서 로 차이가 발생하였다.

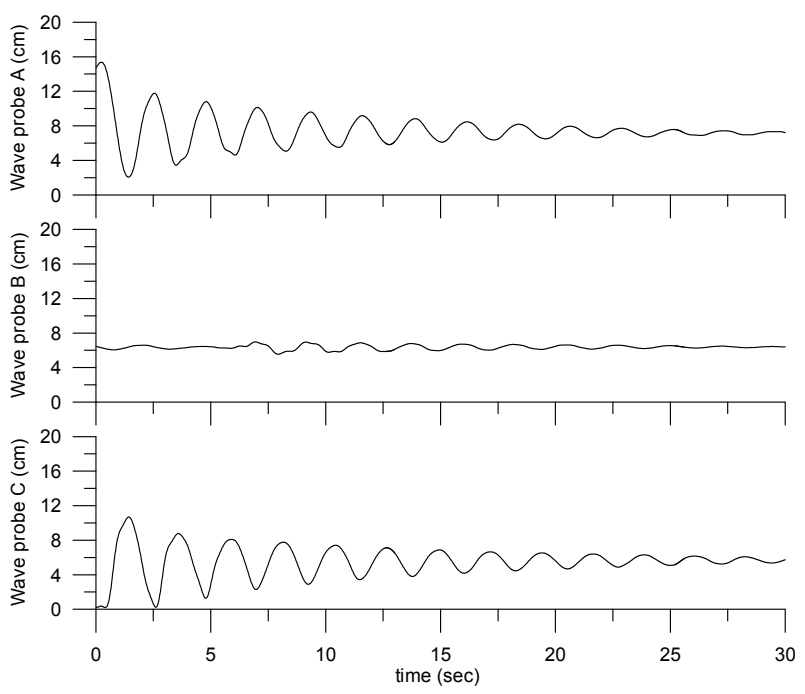

Fig. 7 Time histories of wave elevations of flooded water inside the damaged compartment

Fig. 8은 모형선 내부에 설치한 비디오카메라로 촬영한 침수 유동의 한 주기 동안의 거동을 0.33 초 간격으로 보여주고 있으 며 자유표면의 위치는 점선으로 표시하였다.

파고계로 측정된 수위와 비디오카메라로 촬영한 영상을 통하 여 손상 시 침수 진행 과정을 살펴볼 수 있으며 침수 유량은 약 $2.83 \mathrm{~kg}$ 으로 계산되었다. 또한 횡동요 시계열의 최대값이 발생하 는 시간과 내부 유입수의 수위가 최대가 되는 시간을 비교하여 침수 유동의 위상이 횡동요 위상에 비해 0.01 초 정도 늦다는 것 을 확인하였다. 따라서 침입수의 유동은 선박의 횡동요를 억제하 는 일종의 횡동요 억제 탱크 (anti-rolling tank)와 같은 역할을 하 는 것으로 이해할 수 있다. 예를 들면 선박이 좌현으로 최대한 기 울어져 있다가 우현 쪽으로 움직이려 할 때, 침수 유동이 선박을 좌현으로 기울이려는 모멘트를 발생시켜 횡동요 진폭이 감소하였 을 것이다.
또한 손상 구획의 수문을 통한 침입수의 유출입과 손상 시 수 문이 개방되면서 개방된 수문 모서리 부분이 횡동요 시 유동 박 리를 일으켜 에너지가 소실되고 이것 역시 감쇠 계수를 커지게 하는 원인으로 작용하였을 것이다. 이외에도 손상 구획의 좌우 비대칭으로 유발된 선박의 횡경사에 의한 선형의 변화도 감쇠계 수에 영향을 준 것으로 사료되며 앞서 언급한 여러 요인들에 의 해 손상 선박의 횡동요 감쇠 계수가 비 손상 선박에 비해서 크게 측정된 것으로 추정된다.
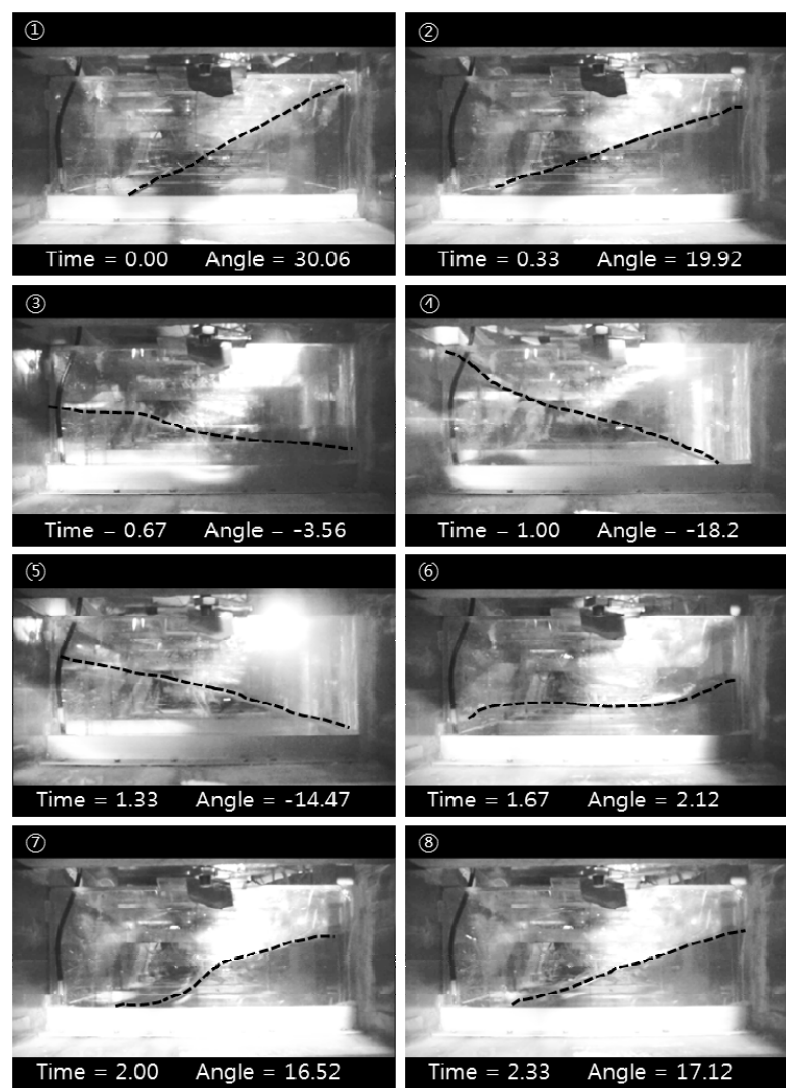

Fig. 8 Snapshots of flooded water inside the damaged compartment $(0.33 \mathrm{sec}$ steps during one period of roll)

\section{5. 결 론}

본 연구에서는 비 손상 시와 손상 상태의 선박에 대한 정수 중 자유 횡동요 감쇠 시험을 수행하여 향후 CFD 계산 결과의 검증 자료로 활용하고자 하였다.

모형시험을 수행할 조건과 침수 구획의 형상을 선정하기 위하 여 모형시험을 수행하기 전, CFD 계산을 통하여 횡파 중 선박의 횡동요 거동 및 손상 구획 내부의 침수 유동을 살펴보았다. 또한 $\mathrm{CFD}$ 계산 프로그램의 차이에 따른 유동 계산의 차이도 확인하였 다.

정수 중 횡동요 감쇠 시험을 통하여 손상 선박의 경우 비 손상 선박에 비해서 횡동요 주기가 길어지며, 횡동요 감쇠 계수가 커 
지는 현상을 확인하였다. 횡동요 주기가 길어지는 원인은 $\overline{G M}$ 의 감소에 기인한 것으로 보이며, 횡동요 감쇠 계수가 커진 원인 은 침수 유동이 일종의 횡동요 억제 탱크와 같은 역할을 한 것과 침입수의 유출입 시 침수 구역 모서리 부분에 의한 유동 박리 효 과 등으로 추정된다. 그러나 손상 선박의 횡동요 감쇠 계수가 증 가한 것이 선박이 더 안정한 것을 의미하지는 않는다. 그 이유는 손상 선박의 경우 건현이 낮아져서 갑판이 침수될 가능성이 커지 고 횡 메타센터 반경이 작아지며, 손상 시 경사시험으로 확인되 었듯이 $\overline{G M}$ 이 감소하여 초기 횡복원력이 줄어들었기 때문에 복 원 안정성은 오히려 나빠진 것으로 이해할 수 있기 때문이다.

향후 파랑 중 모형시험을 통하여 손상 시 선박의 거동과 내부 로 유입된 유동을 측정하여 $\mathrm{CFD}$ 계산 결과의 검증을 위한 자료 를 확보할 예정이다.

\section{후 기}

본 연구는 교육과학기술부 (R32-2008-000-10161, 20090093129, 2010-0022835)의 지원으로 수행되었으며, 지원에 감 사드립니다.

\section{참 고 문 헌}

Chen, H.C. Liu, T. Chang, K.A. \& Huang, E.T., 2002. Time-Domain Simulation of Barge Capsizing by a Chimera Domain Decomposition Approach, Proceedings of The Twelfth(2002) International Offshore and Polar Engineering Conference, Kitakyushu, Japan, 26-31 May 2002.

Cho, S. Hong, S. \& Kim, Y., 2006. Investigation of Dynamic Characteristics of the Flooding Water of the Damaged Compartment of an ITTC RoRo-Passenger. Journal of the Society of Naval Architects of Korea, 43(4), pp.451-459.
Palazzi, L. \& Kat, J., 2004. Model Experiments and Simulations of a Damaged Ship With Air Flow Taken Into Account, Marine Technology, 41(1), pp. 38-44.

Papanikolaou, D. et al., 2000. Investigation Into the Capsizing of Damaged RO-RO Passenger Ships in Waves, International Conference on Stability of Ship and Ocean Vehicles (STAB), Tasmania, Australia, 7-11 February 2000.

Ruponen, P., 2007. Progressive Flooding of a Damaged Passenger Ship, Doctoral Dissertation, Department of Mechanical Engineering, Helsinki University of Technology.
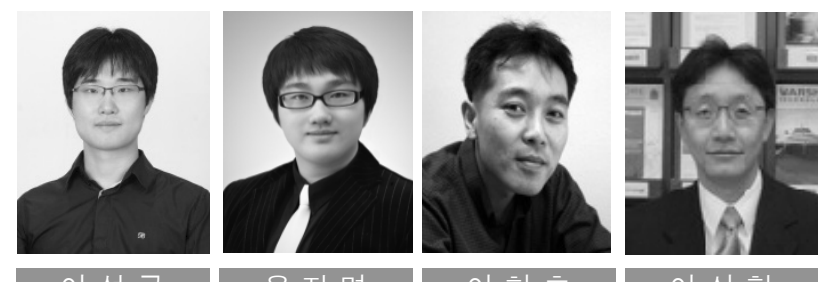

이 성 균

유지 명

이 현 호

이 신 형

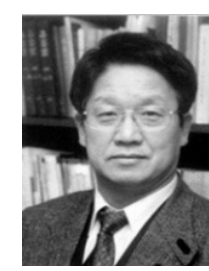

이기 표 